\title{
The Vietnam War and International Law
}

\section{Volume 4: The Concluding Phase}

Edited by Richard A. Falk

This concluding volume of The Vietnam War and International Law focuses on the last stages of America's combat role in Indochina. Contributors to this volume-lawyers, scholars, and government officials-include Dean Rusk, Eugene V. Rostow, Richard A. Falk, John Norton Moore, and Richard Wasserstrom.

Sponsored by the American Society of International Law

Cloth, $\$ 35.00$ - Limited Paperback Edition, $\$ 13.50$

Publishers of THE ARAB-ISRAELI CONFLICT,

Edited by John Norton Moore.

Three-vol. set, $\$ 95.00$ - One-vol. edition: Cloth, $\$ 30.00$ - Paper, $\$ 13.50$

\section{PRINCETON UNIVERSITY PRESS}

Princeton, New Jersey 08540

\section{Jntermational $\mathbf{L}$ aw Perspectibe}

To the acclaim of international lawyers and scholars worldwide, International Law Perspective is a timesaving and highly informative monthly report available to all those who are interested and concerned with current developments in international law within the United States. Each issue selects, summarizes, and highlights the important and interesting occurrences in the Congress, the courts, the legal periodicals, and other notable sources. All monthly issues are sent by first-class mail.

Subscription for 12 issues : U.S. \& Canada, $\$ 36.00$; Foreign, $\$ 40.00$

Make check payable to: International Law Perspective

92715 th Street, N.W.

Washington, D.C. 20005 


\section{International Zaw Association}

\section{Publications}

Index of the Conference Reports of the ILA $(1873-1972) \ldots \ldots \ldots \ldots \ldots \ldots \ldots \ldots \ldots \ldots$ US $\$ 11.70$

Report of the 56th Conference: New Delhi, 1974/5 ...... US $\$ 15.00$ (Many earlier Reports are still available)

The Present State of International Law and other Essays (Centenary Volume) $\ldots \ldots \ldots \ldots \ldots$ US $\$ 11.70$

The Effect of Independence on Treaties: a study of State Succession ......................... US $\$ 11.70$

Helsinki Rules on the Uses of the Waters of International Rivers $\ldots \ldots \ldots \ldots \ldots \ldots \ldots \ldots \ldots$ US $\$ 2.00$

(Postage and packing extra in each case.)

Orders to: INTERNATIONAL LAW ASSOCIATION Publications Department

3 Paper Buildings

Temple, London, EC 4

\section{CENTER FOR INTERNATIONAL LEGAL STUDIES}

\section{Postamt 5033 Salzburg Postfach 59 Austria}

\section{SUMMER STUDIES}

University of the Pacific, McGeorge School of Law, summer courses in Salzburg, Vienna, Budapest, June 21-July 23, 1977. Contact Registrar, McGeorge School of Law, 3200 5th Ave., Sacramento, Calif.

\section{LAW INTERNSHIPS}

Seminars, training with firms and institutions in Europe for recent law graduates, leading to Graduate Diploma in Comparative Law, Fall 1977. Contact Center for International Legal Studies, Salzburg.

\section{FURTHER PROGRAMS}

The Center conducts research and legal planning studies, coordinates conferences and symposia, and publishes the Comparative Law Yearbook. The Center invites proposals for appropriate research or conference projects.

BOARD OF ADVISORS: Prof. Rona Aybay, Middle East Technical University; Dr. H. Golsong, Council of Europe; Arthur Glover, educational consultant; Prof. Hans-Georg Koppensteiner, Salzburg University; Justice Gustaf Petren, Swedish Supreme Administrative Court; Dr. Peter Prettenhofer, attorney; Prof. S. F. Richter, Austro-American Institute of Education; Dean Gordon Schaber, McGeorge School of Law; Bruce Zagaris, attorney. 


\section{Join-}

\section{THE AMERICAN SOCIETY OF INTERNATIONAL LAW}

As a member of the Society, you will receive

- four issues each year of the most distinguished journal in the field, THE AMERICAN JOURNAL OF INTERNATIONAL LAW.

- the PROCEEDINGS of the Society's Annual Meeting.

- the opportunity to buy other Society publications at reduced prices, such as the valuable bimonthly documentary, INTERNATIONAL LEGAL MATERIALS, and books published under Society auspices such as THE VIETNAM WAR AND INTERNATIONAL LAW.

- the Society's NEWSLETTER, which keeps you abreast of developments in the field.

- the opportunity to participate in significant, Society-sponsored meetings (the Annual Meeting, regional meetings, study panels).

- occasion to join with others in contributing to the development of international law through the Society's wide-ranging studies and publications.

If you wish to join the Society, please clip out this page, fill out the applica tion on the reverse side, and mail it, together with your check, to the Membership Secretary, American Society of International Law, 2223 Massachusetts Avenue, N.W., Washington, D. C. 20008 . You will receive the Journal and Newsletter for the current year.

Members of whatever profession and nationality are welcome

If you or your institution prefers to subscribe to the Journal, without joining the Soclety, please so indicate on the reverse side. 
Membership Secretary

American Society of International Law

2223 Massachusetts Avenue, N.W.

Washington, D.C. 20008

Please enroll me as a member of the American Society of International

Law: My check, money order, UNESCO coupon, or payment in a convertible currency, is enclosed. I have checked the category of membership for which I am eligible:

[ ] PROFESSIONAL MEMBERS (U.S. residents practicing law other than in government who have been members of the bar for more than 10 years $\ldots \ldots \ldots \ldots \ldots \ldots \ldots \ldots \ldots \$ 40$

I ] RESIDENT REGULAR MEMBERS-residing in the United States ............................\& 30

( ] NON-RESIDENT MEMBERS-not residing in the United States $\ldots \ldots \ldots \ldots \ldots \ldots \ldots \ldots \ldots \ldots \ldots \ldots \ldots \ldots \ldots 22$

1 ] INTERMEDIATE MEMBERS (first 5 years of membership for those under 30 years of age at time of application) . . \$ 15

I ] STUDENT MEMBERS $\ldots \ldots \ldots \ldots \ldots \ldots \ldots \ldots \ldots \ldots \ldots \$ 10$

１] CONTRIBUTING MEMBERS $\ldots \ldots \ldots \ldots \ldots \ldots \ldots \ldots \ldots \$ 50$

( ] SUPPORTING MEMBERS $\ldots \ldots \ldots \ldots \ldots \ldots \ldots \ldots \ldots \ldots 100$

l ] ANNUAL PATRON $\ldots \ldots \ldots \ldots \ldots \ldots \ldots \ldots \ldots \ldots \ldots \ldots \$ 500$

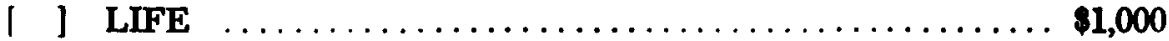

( $\$ 15$ of membership fee is allotted to AJIL subscription)

(Please Print)

Name

Mailing Address

Professional Affiliation:

Nationality

Particular professional interests:

Signature

PLEASE MAKE CHECKS PAYABLE TO The American Soctety of International Law. Contributions above obligatory dues, and all dues if membership is related to your work or profession, are tax deductible in the United States.

Please enter my subscription for the Journal at $\$ 36$ a year 